\title{
Self-supporting tests in lattice joists subject to negative bending
}

\section{Ensaios de autoportância em vigotas treliçadas sujeitas a flexão negativa}
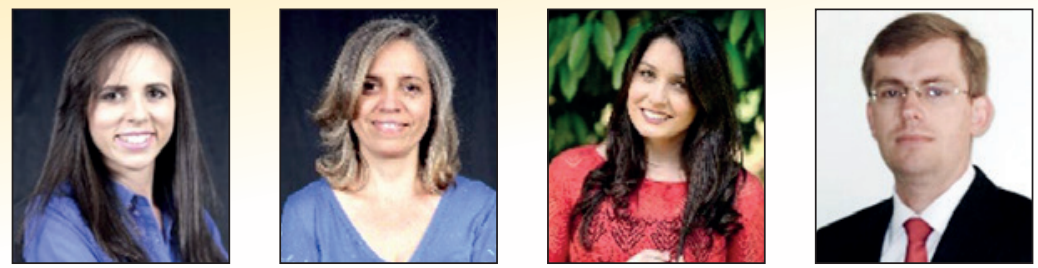

I. STORCH

storch.engcivil@gmail.com

J. G. S. DOBELIN a joslaine.dobelin@ucb.org.br

L. C. BATALHA leticia.cbatalha@hotmail.com

A. L. SARTORTI a

artur.sartorti@ucb.org.br

\begin{abstract}
During the construction of bridges, cantilever roofs and eaves, assembling formworks and scaffold that will support the slabs is a point of difficulty in the construction phase. Therefore, it is relevant the study of the lattice joists which serve as self-supporting formwork, supporting its weight, the weight of the fresh concrete, the weight of workers and the weight of concreting equipment. The analysis of the bearing capacity of lattice joists subject to negative bending with base concrete opening enables checking the maximum span that each lattice truss model bears, either cantilevered or between continuous spans with reduced or no scaffold. The concrete opening enables the monolithism between the slab and its support. This paper presents the results of tests on lattice joist with concrete opening. By the results analysis, formulations for designing the spacing between prop lines were found. The results are promising and indicate great possibilities of using lattice joists with concrete opening over the supports (beams), in order to optimize the slab shuttering.
\end{abstract}

Keywords: self-supporting, shuttering, negative bending, lattice joist, mini lattice panel, buckling.

\section{Resumo}

Em construção de pontes, marquises e beirais, uma das dificuldades encontradas é a montagem de formas e escoramento que darão apoio à laje na fase construtiva. Portanto, apresentam-se relevantes os estudos de vigotas treliçadas que servem como formas autoportantes, suportando, além de seu peso, o peso do concreto fresco, de operários e equipamentos de concretagem. A análise da capacidade portante das vigotas treliçadas sujeitas à flexão negativa com abertura no concreto da base, possibilita a verificação do vão máximo que cada modelo de armadura treliçada suporta em balanço ou entre vãos contínuos com reduzido ou nenhum escoramento. A abertura de concretagem possibilita o monolitismo entre a laje e o seu apoio. Neste artigo são apresentados os resultados de ensaios em vigotas treliçadas com abertura de concretagem na base. Com a análise dos resultados realizada foram encontradas as formulações que permitem o dimensionamento do espaçamento entre linhas de escora. Adianta-se que os resultados encontrados são promissores e indicam grandes possibilidades da utilização de vigotas treliçadas com abertura de concretagem sobre os apoios (vigas), com o objetivo de otimizar o cimbramento da laje.

Palavras-chave: autoportância, cimbramento, momento negativo, vigota treliçada, minipainel treliçado, flambagem.

Centro Universitário Adventista de São Paulo, Engenharia Civil, Engenheiro Coelho, SP, Brasil. 


\section{Introduction}

The manufacturing of lattice slabs started in Brazil after the implementation of the first electroplating machine, using steels grade 600 . According to the Brazilian code ABNT NBR 14862 [1], lattice reinforcement is a precast element with a three-dimensional prismatic mold, made of two steel wires in the bottom and one steel wire in the top which form its lower and upper flanges, respectively. These elements are connected by electrofusion to two steel wires, called sinusoid (diagonal bars), following a regular $20 \mathrm{~cm}$ spacing, known as step and worldwide standardized. The lattice girders are identified for a TR code followed by two digits that represent its height in centimeters. The last three digits represent respectively the upper flange, sinusoid and lower flange diameters, in millimeters.

The code ABNT NBR 14859-1 [2] regulates the precast lattice joists fabrication (VT) with a base of concrete. The lattice girder partially embedded in the concrete base provides a light element easy to handle, requiring fewer shuttering components according to its selfsupporting capacity (SARTORI [3]). The joists can be reinforced or not, depending on its structural demand. These constructive elements are normalized according to ABNT NBR 14859-1 [2]; ABNT NBR 14859-2 [4]; ABNT NBR 14860-1 [5]; ABNT NBR 14860-2 [6]; ABNT NBR 14862 [1] and ABNT NBR 15696 [7], reporting to ABNT NBR 6118 [8]. Figure $1 A$ illustrates a lattice joist cross section. The combination of two or more lattice girders comprises mini panels (Figure 1B) and lattice girder panels (Figura 1C).

Gaspar [10] concluded that the lattice joist bearing capacity during the construction phase, considering sagging moments, is governed by the upper flange buckling. The upper flange is characterized by its diameter and diagonal stiffness. As the vertical forces increase, the upper flange is progressively compressed in bending (sagging moment) possibly causing instability or buckling. It is also argued that the shuttering assembly is necessary so that the structure doesn't achieve its ultimate capacity, minimizing the elements stresses. Terni et al [11] developed researches using computer programs in order to analyze this behavior in the upper flanges. Sartorti et al [3] developed experimental studies with positive bending and shear in lattice joists subject to sagging moments, aiming to provide data about the calculation of spacing between prop lines. It also aimed to obtain a more economic construction process, eliminating issues during the construction phase and ensuring security. The later authors concluded that the element ruin can also be characterized by its diagonal bars buckling - for joists with a height of $25 \mathrm{~cm}$ or more - besides the upper flange buckling, which is more frequent in joists with $20 \mathrm{~cm}$ height or less.

In another occasion, Sartorti et al [9] affirmed that the following situations shall be considered for a self-supporting structure calculation in the ultimate limit state: the upper flange buckling due to sagging moments, the lower flange buckling due to hogging moments, the sinusoid shear buckling, failure for excessive plastic deformation of the tension bars and failure of the welded node due to shear. For the serviceability limit states, the calculation of this elements shall consider the analysis of its vertical displacements. The assemblage of formwork and shuttering elements is a challenge during the construction of bridges and overpasses. Regarding to this issue, the use of lattice elements is an interesting solution whereas its concrete base works as a self-supporting formwork for the slabs. The reinforcement composing the lattice trusses helps bearing the forces acting in the structure in the serviceability state. The use of these latticed elements dispense the need of many transportation

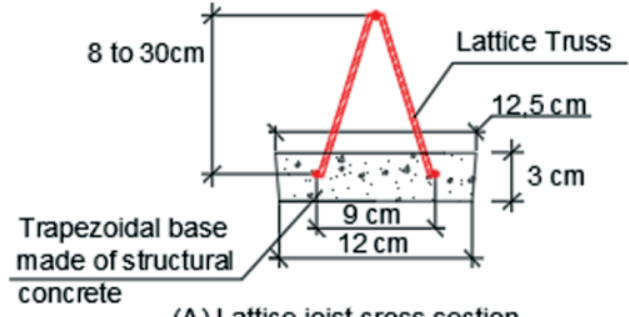

(A) Lattice joist cross section

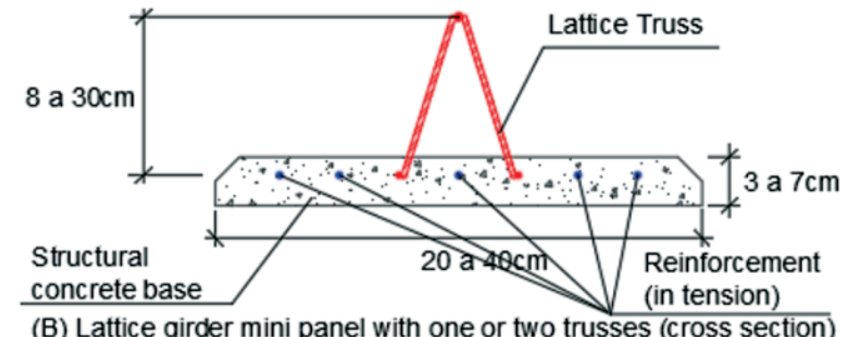

(B) Lattice girder mini panel with one or two trusses (cross section)

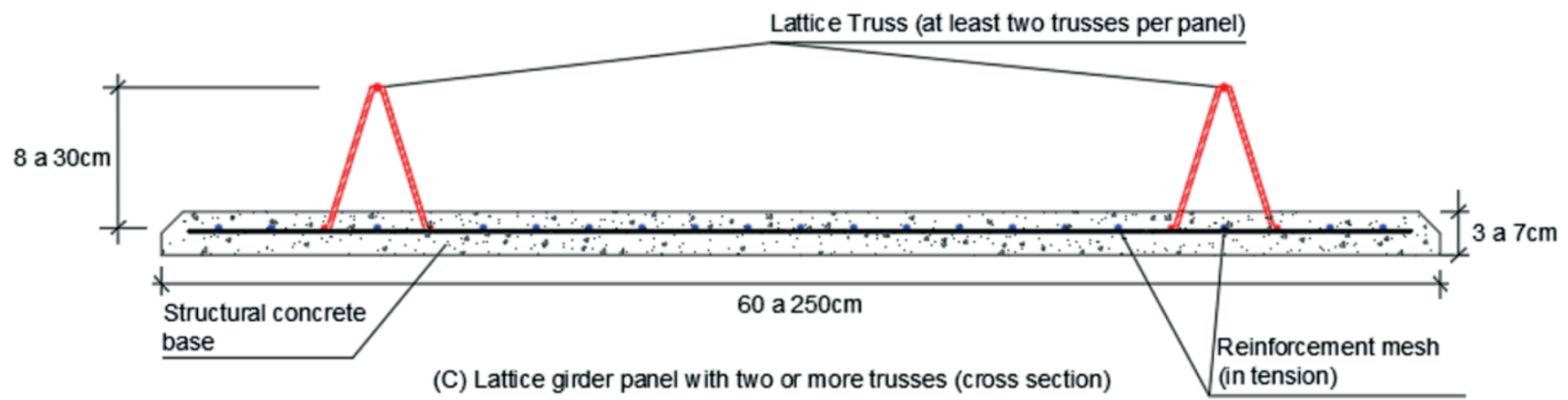

Figure 1

Lattice girder joist and lattice girder panels (cross section scheme)

Source: Adapted from SARTORTI et al [9] 

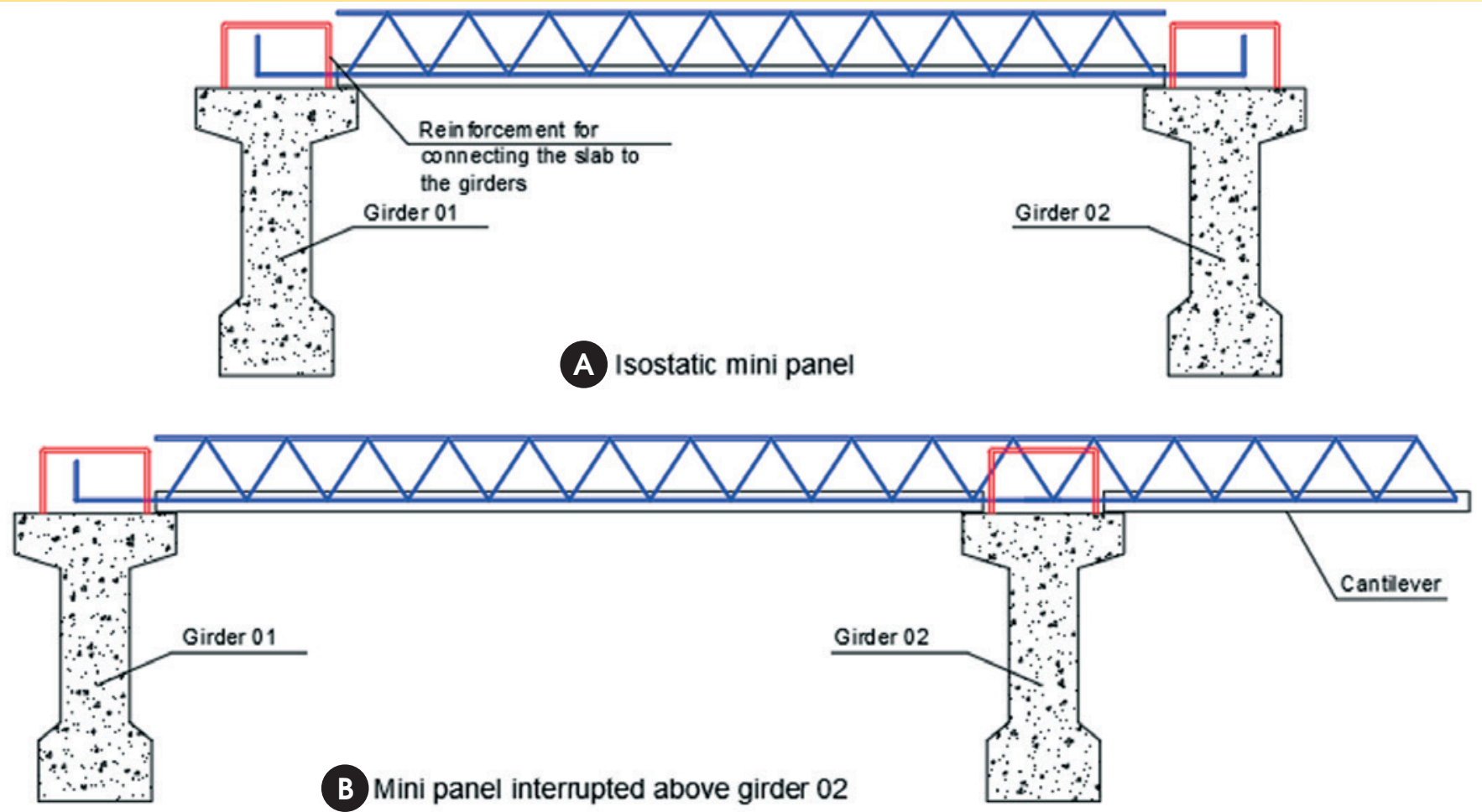

Figure 2

Usual kinds of mini panels used for bridge decks

Source: SARTORTI et al [9]

equipment, making it easy to handle. This combination of factors results in sustainability and cost saving.

Self-supporting lattice slabs can be used usually in two different manners: simply supported, according to Figure $2 \mathrm{~A}$, or with discontinuous concrete joists - particularly the joist located over the supports - making it possible a monolithic joining between the bridge girder and its deck, as shown in Figure 2B.

This research aimed to expand the knowledge concerning self-supporting lattice joists, analyzing its behavior when subject to negative bending and concrete opening (discontinuous concreting) over the supports (Figure 2B). Therefore, the behavior of the steel bars from the lower flange and sinusoids were analyzed, measuring the maximum load bearing capacity of a lattice joist until the serviceability limit state of excessive deformation and the ultimate limit state of instability of any of the latticed components. It was determined the real effective buckling length necessary to the calculation of the maximum span either in cantilever or between supports with no shuttering.

\section{Characteristics of the negative bending tests}

This item describes the main characteristics of the experimental program.

\subsection{Lattice joists}

The models of lattice trusses used for the lattice joists are described in Table 1 and its longitudinal and cross section are illustrated in Figures $1 \mathrm{~A}$ and 3 , respectively. For each truss height (6, $8,10,12,16,20,25$ and $30 \mathrm{~cm}$ ) there are nine models - three of them with $20 \mathrm{~cm}$ concreting interruption, three of them with $30 \mathrm{~cm}$ concreting interruption and other three with $40 \mathrm{~cm}$ concreting interruption, in a total of 72 lattice joists.

The concrete bases of the joists were cast using the cement type CP V-ARI, with a self-compacting concrete ratio of

\section{Table 1}

Lattice reinforcement characteristics

Lattice reinforcement

\begin{tabular}{|c|c|c|c|c|}
\hline \multicolumn{5}{|c|}{ Lattice reinforcement } \\
\hline \multirow{2}{*}{ Truss code } & \multirow{2}{*}{ Height $(\mathbf{c m})$} & Upper & Sinusoid & Lower \\
\cline { 2 - 5 } & 6 & 6 & 4.2 & 4.2 \\
\hline TR 06 644 & 8 & 6 & 4.2 & 4.2 \\
\hline TR 08 644 & 10 & 6 & 4.2 & 4.2 \\
\hline TR 10 644 & 12 & 6 & 4.2 & 4.2 \\
\hline TR 12 644 & 16 & 7 & 4.2 & 5 \\
\hline TR 16 745 & 20 & 7 & 4.2 & 5 \\
\hline TR 20 745 & 25 & 7 & 5 & 6 \\
\hline TR 25 756 & 30 & 8 & 5 & 6 \\
\hline TR 30 856 & & & & \\
\hline
\end{tabular}



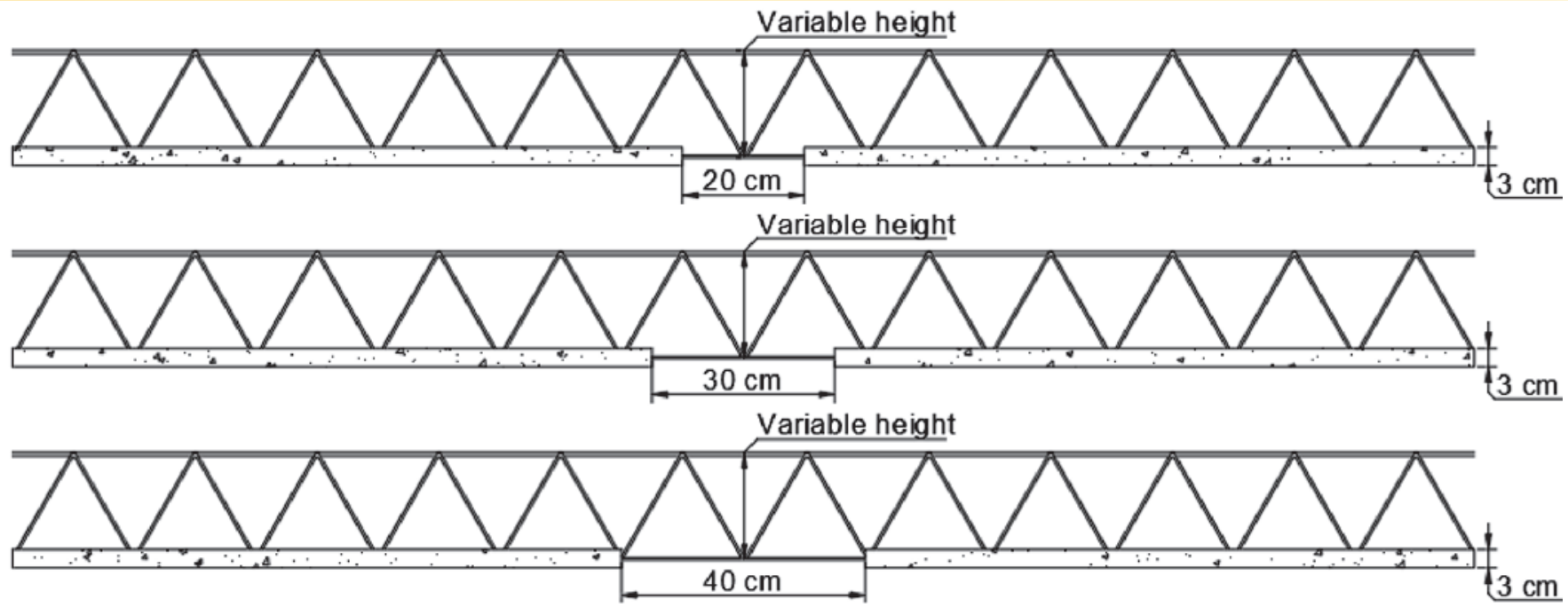

Figure 3

Longitudinal section of the lattice joists models with total length of $240 \mathrm{~cm}$. The concrete opening in the central region in indicated

Source: Authors

$1: 1.526: 2.589: 0.555: 0.375 \%$ that are in volume cement: fine sand: stone (type 0): water: superplasticizer, in volume. The base cross section has a width of $12 \mathrm{~cm}$, a height of $3 \mathrm{~cm}$ and a length of $240 \mathrm{~cm}$. For the 72 joists, 15 mixtures in a concrete mixer were necessary, regarding to the concrete mixer capacity. Three concrete cylinder tests were conducted for each mix of concrete, expect for the last one, where six concrete cylinders were taken for the determination of the dynamic modulus of elasticity and its characteristic bearing capacity under compression loads.

\subsection{Set-up of the bending tests}

The bending tests were carried out at a concrete age of 50 days. The following equipment were used: servo-hydraulic universal testing machine (1000 kN capacity); dial indicators with a stroke of $50 \mathrm{~mm}$ and a precision of $0.01 \mathrm{~mm}$; magnetic supports for the dial indicators; steel beam used as struts and wood elements used for loading.

The joists were positioned with its upper flange downwards and put above wooden supports which served as pinned supports located
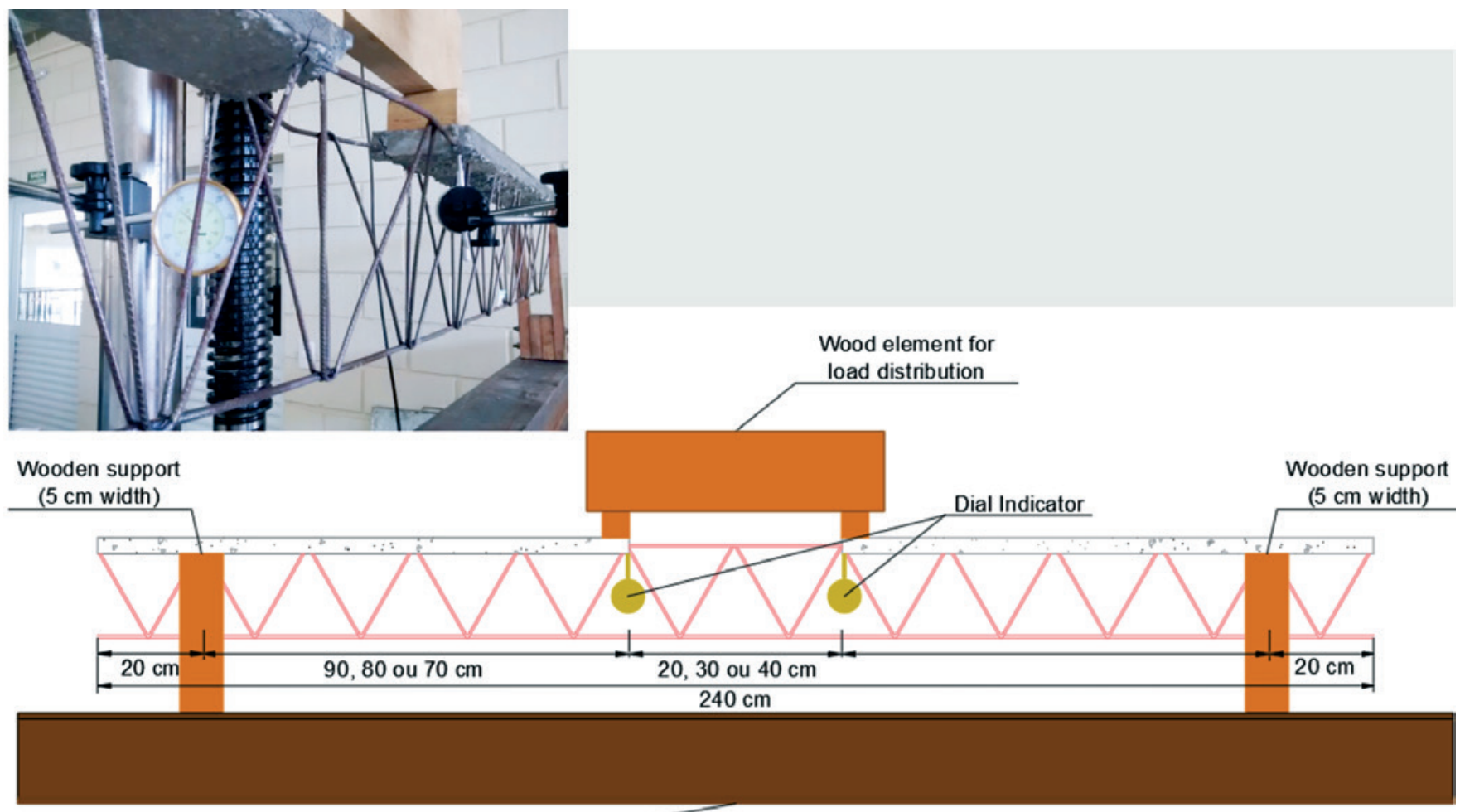

I-shaped steel beam support

\section{Figure 4}

Test set-up: positioning of joists, devices for bending test and dial indicators 


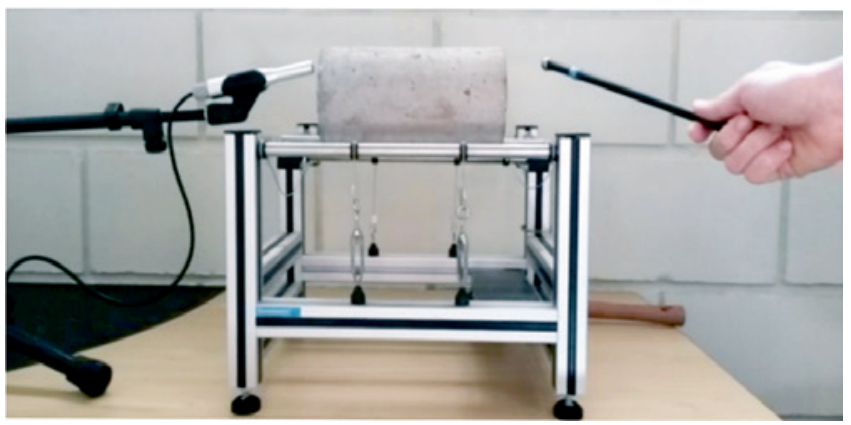

Figure 5

Sonelastic ${ }^{\circledR}$ test set-up: specimen positioning

at $20 \mathrm{~cm}$ from the edges of the joist. These wood elements were supported over an I-shaped steel beam. For the distribution of the applied load in two points, two wood pieces were positioned in the edges right before the space where there was no concrete. Five centimeters is a usual value for the width of the bearings of footing under the lattice joists in real structures, what explains the choice of this value for the wood elements width. Vertical displacements due to the loading were measured by two dial indicators (R1 e R2) in the points of loading. The dial indicators were always positioned in the same region in different sides of the joists, according to Figure 4. Displacements due to the self-weight of the lattice joists were not measured. The test set-up is shown in Figure 4.

\section{Tests results}

This item presents the results of concrete cylinder tests and negative bending tests.

\subsection{Concrete specimens}

The concrete cylinders for each concrete mixture were tested by the age of 50 days, measuring its Young's modulus and compressive strength. The Young's modulus was measured by an acoustic emission non-destructive test. The cylinder is exposed to an impulse which measures the dynamic modulus of elasticity. The
Sonelastic ${ }^{\circledast}$ equipment was used for this purpose. Its functioning is quite simple and the tests can be repeated many times as they are not destructive.

For better understanding this equipment functioning, the following steps can be idealized:

a) The weight and geometry of the specimens are measured and registered in the Sonelastic ${ }^{\circledR}$ computer program;

b) The specimen is positioned under the wires in the nodal points of flexional resonance $-0.224 \mathrm{~L}$ from the edge of the specimen, where $L$ is its length;

c) Using a pre-determined mass impactor, the specimen suffers an impact providing a sound;

d) The impact sound is recorded by an acoustic conventional receptor (microphone). Two natural frequencies (flexional and longitudinal) of the specimen are contained in the sound waves;

e) The computer program performs a Fast Fourier Transform (FFT) in order to identify the natural frequencies of the specimen;

f) Equations from ASTM E1876-1 [12] are used for calculating the modulus of elasticity having the values of the natural frequencies. Emphasis is given for the fact that the modulus of elasticity is a unique property of the material. The difference between flexional and longitudinal frequencies exists only because of the way they are obtained. Figure 5 illustrates the set-up of the described test. For more information about Sonelastic ${ }^{\circledR}$ it is recommended reading Sartorti [13].

The values obtained by this method are $20 \%$ to $40 \%$ higher than the ones obtained with static tests, according to Mehta and Monteiro [14]. A great advantage observed from the dynamic tests is the small variability of results, in sharp contrast with the static tests. Figure 6 shows the results of dynamic elasticity modulus for each concrete mixture.

The axial compression test results are presented in Figure 7. Each specimen has a strength value $f_{c i}$. The mean value for all the specimens is $f_{c m}$. Fusco [15] indicates an expression for calculating the characteristic strength of a tested concrete (Equation 1):

$f_{c k}=f_{c m}-1,645 . s$

Where $f_{c k}$ is the characteristic compressive concrete cylinder strength (by the age of 28 days), with $5 \%$ probability of being

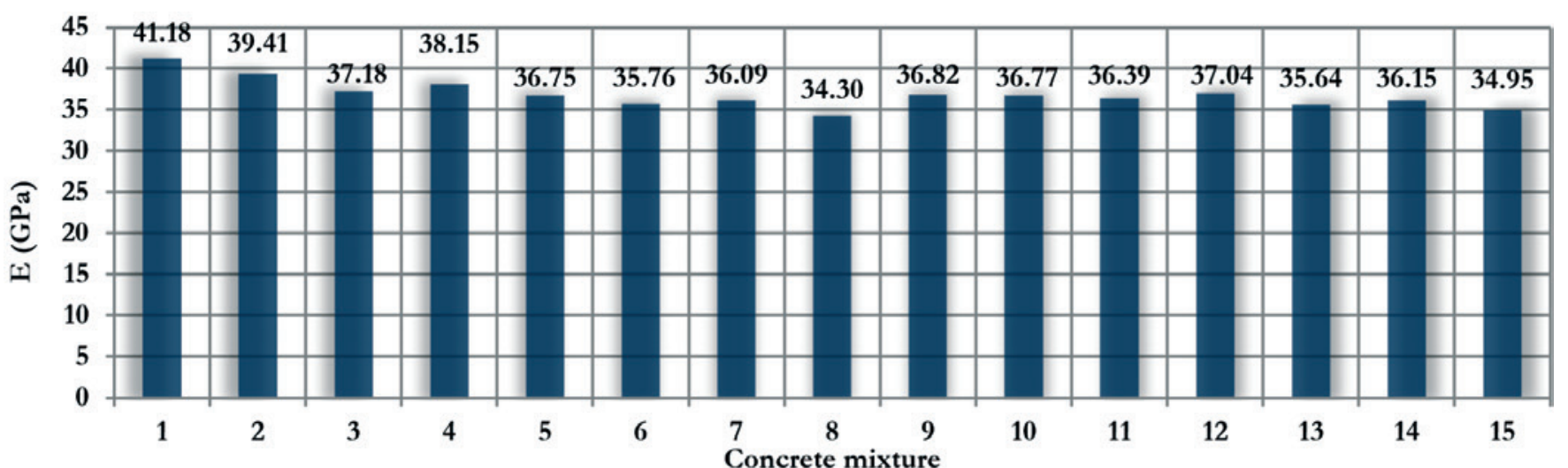

Figure 6

Elasticity modulus test results for each concrete mixture 


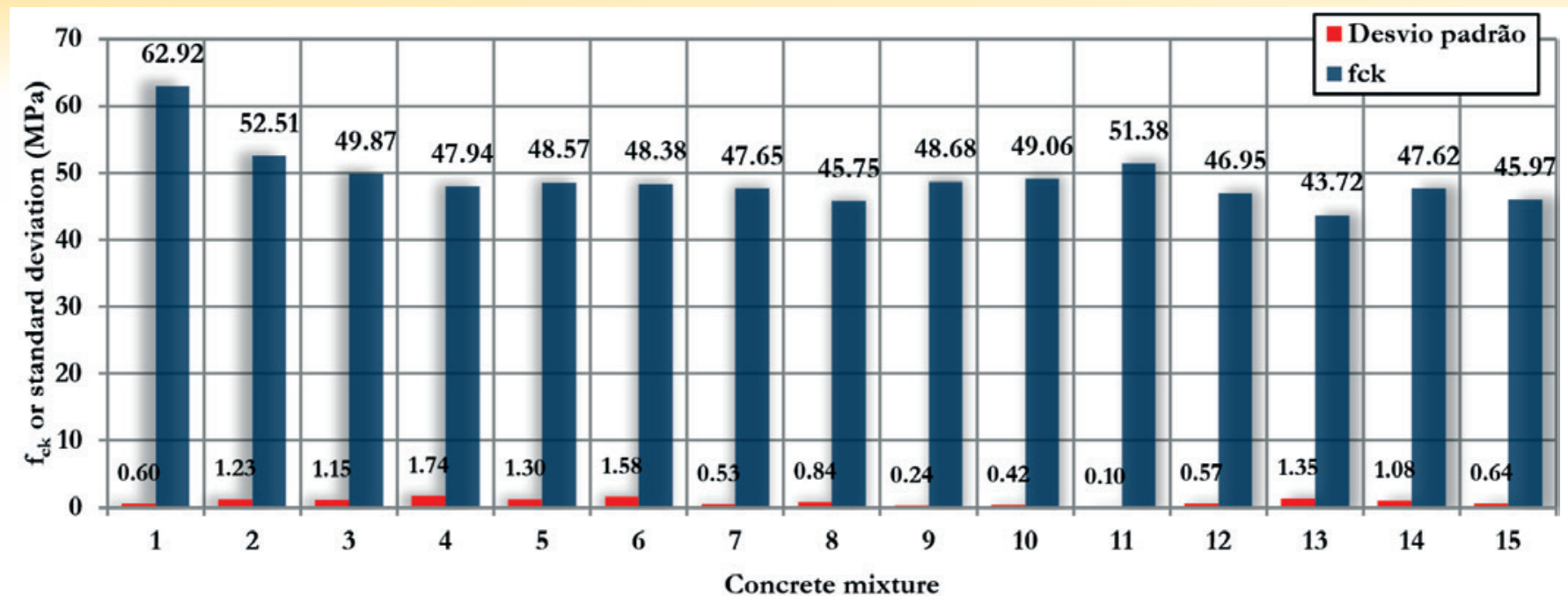

Figure 7

Results of $f_{c k}$ and standard deviation for each concrete mixture

unfavorably exceeded, $f_{c m}$ is the mean concrete compressive strength, $s$ is the standard deviation obtained by $s=f_{c m} . \delta$, and $\delta$ is the variance defined by Equation 2, with $\mathrm{N}=$ total number of specimens.

$\delta=\sqrt{\left(\frac{1}{N}\right) \cdot \sum_{i=1}^{N}\left[\frac{\left(f_{c i}-f_{c m}\right)}{f_{c m}}\right]^{2}}$

A variation of $f_{c k}$ results between different concrete mixtures was observed, even when the same ratio was used for the mixes. A small number of cylinder specimens were available for each mixture (equipment limitation), the high room temperature and the low air humidity are some of the reasons attributed by the authors to this variation. Therefore, the different range of time for molding the specimens shall have occasioned the loss of kneading water for the atmosphere, increasing the $f_{c k}$ results variation.

\subsection{Negative bending test results}

Each of the bending tests resulted in a load versus vertical displacement curve, as shown in Figure 8. There were obtained two important parameters: the maximum joist load bearing capacity and the maximum load that corresponds to the maximum displacement.

\section{Analysis of results}

The analysis of the lattice joists tests aims to define a real effective buckling length for the elements which failure during the test set-up (see Table 2).

After defining the real effective length of joists, mini panels and trussed panels it is possible to use this results in designing situations, in cases when the structural element has a concrete opening and is subject to hogging moments in the opening region. Aiming

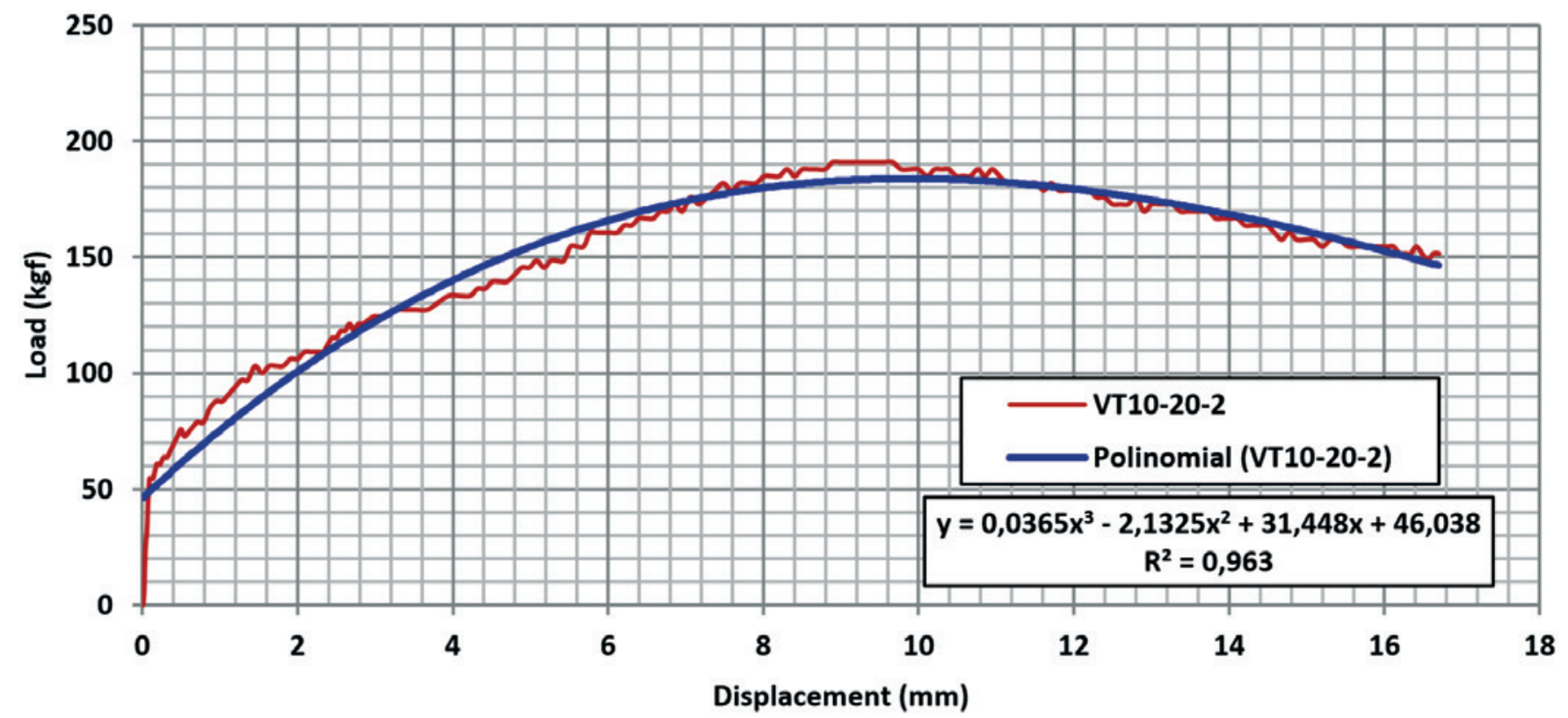

Figure 8

Load versus vertical displacement for the VT 20-30-2 joist (lattice joist $10 \mathrm{~cm}$ height; concrete opening of $20 \mathrm{~cm}$; second from the three samples tested under the same conditions) 

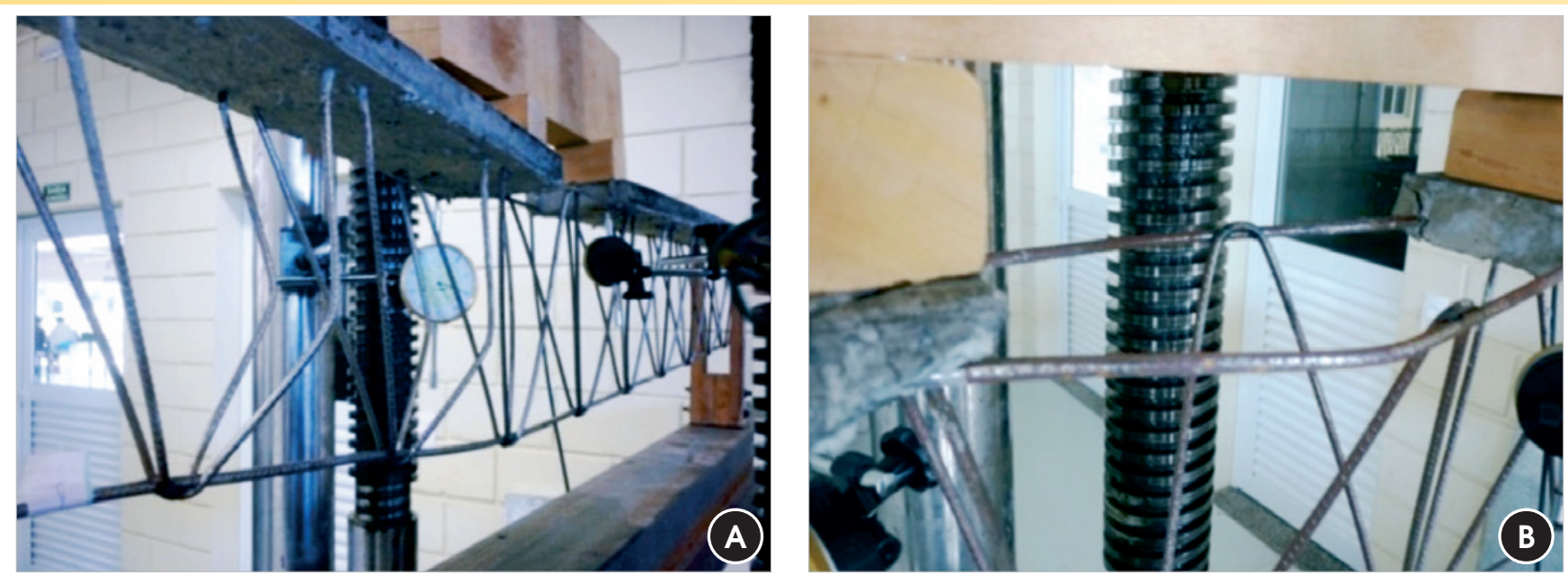

Figure 9

Failure modes: (A) diagonal buckling; (B) lower flange buckling

Table 2

Results for the negative bending tests (Part 1)

\begin{tabular}{|c|c|c|c|c|c|}
\hline Modelo & $\mathrm{pp}(\mathrm{kN})$ & $\mathrm{PD}(\mathrm{kN})$ & $F_{\text {failure }}(k N)$ & $F_{\text {limit }}(k N)$ & Failure mode \\
\hline VT 06201 & 0.2085 & 0.036 & 1.5758 & 1.0606 & Lower flange buckling \\
\hline VT 06202 & 0.2085 & 0.036 & 1.4242 & 1.0303 & Lower flange buckling \\
\hline VT 06203 & 0.2150 & 0.036 & 1.4545 & 1.0303 & Lower flange buckling \\
\hline VT 06301 & 0.1925 & 0.036 & 1.3333 & 1.0606 & Lower flange buckling \\
\hline VT 06302 & 0.1935 & 0.036 & 1.3030 & 0.9697 & Lower flange buckling \\
\hline VT 06303 & 0.1905 & 0.036 & 1.2727 & 0.9697 & Lower flange buckling \\
\hline VT 06401 & 0.1905 & 0.036 & 1.2727 & 1.0909 & Lower flange buckling \\
\hline VT 06402 & 0.1785 & 0.036 & 1.3636 & 1.0606 & Lower flange buckling \\
\hline VT 06403 & 0.1850 & 0.036 & 1.0303 & 0.8485 & Lower flange buckling \\
\hline VT 08201 & 0.2175 & 0.036 & 1.6667 & 1.4242 & Lower flange buckling \\
\hline VT 08202 & 0.1990 & 0.036 & 1.6970 & 1.2121 & Lower flange buckling \\
\hline VT 08203 & 0.2090 & 0.036 & 1.9394 & 1.4545 & Lower flange buckling \\
\hline VT 08301 & 0.1970 & 0.036 & 1.3939 & 1.1818 & Lower flange buckling \\
\hline VT 08302 & 0.1940 & 0.036 & 1.4242 & 1.2121 & Lower flange buckling \\
\hline VT 08303 & 0.1775 & 0.036 & 1.3636 & 1.0909 & Lower flange buckling \\
\hline VT 08401 & 0.1965 & 0.036 & 1.3939 & 1.2121 & Lower flange buckling \\
\hline VT 08402 & 0.1815 & 0.036 & 1.1818 & 1.0606 & Lower flange buckling \\
\hline VT 08403 & 0.1910 & 0.036 & 1.3030 & 1.0606 & Lower flange buckling \\
\hline VT 10201 & 0.2200 & 0.036 & 1.7273 & 1.3636 & Lower flange buckling \\
\hline VT 10202 & 0.2175 & 0.036 & 1.9091 & 1.3333 & Lower flange buckling \\
\hline VT 10203 & 0.2085 & 0.036 & 1.6061 & 1.4545 & Lower flange buckling \\
\hline VT 10301 & 0.2230 & 0.036 & 1.3636 & 1.2727 & Lower flange buckling \\
\hline VT 10302 & \multicolumn{5}{|c|}{ Not used due to data error } \\
\hline VT 10303 & 0.2055 & 0.036 & 1.4242 & 1.2727 & Lower flange buckling \\
\hline VT 10401 & 0.1940 & 0.036 & 1.2727 & 1.2121 & Lower flange buckling \\
\hline VT 10402 & 0.1650 & 0.036 & 1.5152 & 1.4242 & Lower flange buckling \\
\hline VT 10403 & 0.1955 & 0.036 & 1.3030 & 1.2424 & Lower flange buckling \\
\hline VT 12201 & 0.1935 & 0.036 & 2.2121 & 1.6061 & Lower flange buckling \\
\hline VT 12202 & 0.2000 & 0.036 & 2.0606 & 1.6364 & Lower flange buckling \\
\hline VT 12203 & 0.1865 & 0.036 & 1.8788 & 1.6061 & Lower flange buckling \\
\hline VT 12301 & 0.1935 & 0.036 & 1.3636 & 1.3636 & Lower flange buckling \\
\hline VT 12302 & 0.1745 & 0.036 & 1.5455 & 1.5152 & Lower flange buckling \\
\hline VT 12303 & 0.1880 & 0.036 & 1.7273 & 1.6364 & Lower flange buckling \\
\hline VT 12401 & 0.1755 & 0.036 & 1.5455 & 1.3333 & Lower flange buckling \\
\hline VT 12402 & 0.1940 & 0.036 & 1.2121 & 1.1515 & Lower flange buckling \\
\hline VT 12403 & 0.1955 & 0.036 & 1.2121 & 1.1515 & Lower flange buckling \\
\hline
\end{tabular}


to define the real effective length, the subsequent scheme for the tested lattice joists will be considered (Figure 10).

For the scheme, $\boldsymbol{a}$ is a fixed dimension of $20 \mathrm{~cm}$ for all the present tests; $\vee \boldsymbol{b}$ is a measure dependent on $\boldsymbol{c}$, and can be calculated by $\boldsymbol{b}=120-\boldsymbol{a}-0,5 . \boldsymbol{c} ; \boldsymbol{c}$ is the concrete opening value, taken either as 20,30 or $40 \mathrm{~cm}$ in this research; $\boldsymbol{p p}$ is the lattice joist self

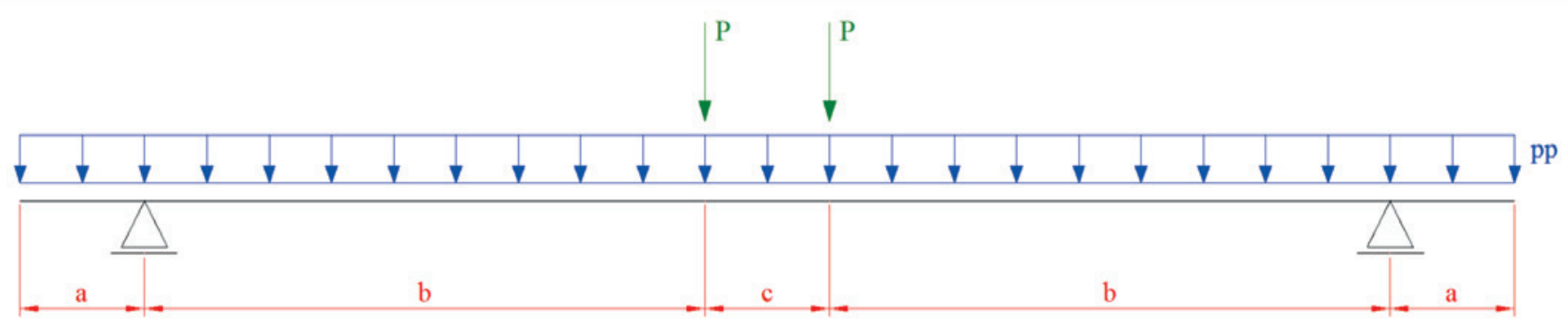

Figure 10

Static scheme of the tested lattice joists

Source: Authors

\section{Table 2}

Results for the negative bending tests (Part 2)

\begin{tabular}{|c|c|c|c|c|c|}
\hline Modelo & $\mathrm{pp}(\mathrm{kN})$ & $\mathrm{PD}(\mathrm{kN})$ & $F_{\text {foilure }}(k N)$ & $F_{\text {limit }}(k N)$ & Failure mode \\
\hline VT 16201 & 0.2110 & 0.036 & 4.1212 & 2.6364 & Lower flange buckling \\
\hline VT 16202 & 0.2060 & 0.036 & 3.5758 & 2.2424 & Lower flange buckling \\
\hline VT 16203 & 0.2140 & 0.036 & 3.8788 & 2.6061 & Lower flange buckling \\
\hline VT 16301 & 0.2140 & 0.036 & 2.6061 & 2.1818 & Lower flange buckling \\
\hline VT 16302 & 0.2255 & 0.036 & 2.3030 & 2.2424 & Lower flange buckling \\
\hline VT 16303 & 0.2165 & 0.036 & 2.5455 & 2.3333 & Lower flange buckling \\
\hline VT 16401 & 0.1990 & 0.036 & 2.1515 & 2.1515 & Lower flange buckling \\
\hline VT 16402 & 0.2045 & 0.036 & 2.1818 & 2.1818 & Lower flange buckling \\
\hline VT 16403 & 0.2060 & 0.036 & 2.2727 & 2.2727 & Lower flange buckling \\
\hline VT 20201 & 0.2290 & 0.036 & 3.2727 & 2.2121 & Lower flange buckling \\
\hline VT 20202 & 0.2325 & 0.036 & 3.0000 & 2.0909 & Lower flange buckling \\
\hline VT 20203 & 0.2365 & 0.036 & 3.6667 & 2.1818 & Lower flange buckling \\
\hline VT 20301 & 0.2005 & 0.036 & 3.0000 & 3.5758 & Lower flange buckling \\
\hline VT 20302 & 0.1915 & 0.036 & 3.4242 & 2.6970 & Lower flange buckling \\
\hline VT 20303 & 0.2115 & 0.036 & 2.9394 & 2.6667 & Lower flange buckling \\
\hline VT 20401 & 0.1840 & 0.036 & 2.5455 & 2.3333 & Lower flange buckling \\
\hline VT 20402 & 0.2055 & 0.036 & 2.2424 & 2.1212 & Lower flange buckling \\
\hline VT 20403 & 0.1970 & 0.036 & 2.0606 & 1.8485 & Lower flange buckling \\
\hline VT 25201 & \multicolumn{5}{|c|}{ Not used due to data error } \\
\hline VT 25202 & 0.2305 & 0.036 & 6.6970 & 2.5758 & Diagonal buckling \\
\hline VT 25203 & 0.2365 & 0.036 & 6.9697 & 3.0909 & Diagonal buckling \\
\hline VT 25301 & 0.2250 & 0.036 & 6.6667 & 3.0000 & Lower flange buckling \\
\hline VT 25302 & 0.2225 & 0.036 & 4.9091 & 3.6364 & Lower flange buckling \\
\hline VT 25303 & 0.2395 & 0.036 & 6.4545 & 2.7576 & Lower flange buckling \\
\hline VT 25401 & 0.2240 & 0.036 & 4.8788 & 3.2727 & Lower flange buckling \\
\hline VT 25402 & 0.2295 & 0.036 & 4.7879 & 3.4545 & Lower flange buckling \\
\hline VT 25403 & 0.2300 & 0.036 & 4.9697 & 3.0000 & Lower flange buckling \\
\hline VT 30201 & 0.2365 & 0.036 & 6.0606 & 3.5758 & Diagonal buckling \\
\hline VT 30202 & 0.2325 & 0.036 & 6.3939 & 3.2727 & Diagonal buckling \\
\hline VT 30203 & 0.2375 & 0.036 & 5.8788 & 3.5152 & Diagonal buckling \\
\hline VT 30301 & 0.2435 & 0.036 & 6.3636 & 3.3030 & Lower flange buckling \\
\hline VT 30302 & 0.2220 & 0.036 & 6.4242 & 3.6364 & Lower flange buckling \\
\hline VT 30303 & 0.2170 & 0.036 & 6.3939 & 3.9091 & Diagonal buckling \\
\hline VT 30401 & 0.2165 & 0.036 & 5.0000 & 3.4848 & Lower flange buckling \\
\hline VT 30402 & 0.2160 & 0.036 & 4.9394 & 3.9394 & Lower flange buckling \\
\hline VT 30403 & 0.2140 & 0.036 & 5.1818 & 4.0000 & Lower flange buckling \\
\hline
\end{tabular}


weight action divided by $240 \mathrm{~cm}$ (Table 2); and $\boldsymbol{P}$ is the applied load $\left(\mathrm{F}_{\text {failure }}\right)$ added to the weight of the test equipment (PD) (Table 2) divided by 2 .

The maximum bending moment and shear force acting on each joist can be calculated for the scheme illustrated in Figure 10. The maximum values of the bending moment $\boldsymbol{M}_{\text {max }}$ (middle joist span) and shear force $\boldsymbol{V}_{\max }$ (internally to any of the supports) can be calculated by Equations 3 and 4 .

$$
\begin{aligned}
& M_{\text {máx }}=\frac{p p \cdot c^{2}}{8}+\left[P+p p \cdot\left(a+b+\frac{c}{2}\right)\right] \cdot b-p p \cdot a \cdot\left(\frac{a}{2}+b\right) \\
& V_{\text {máx }}=P+p p \cdot\left(b+\frac{c}{2}\right)
\end{aligned}
$$

The results analysis is divided into three groups. The first one comprises the joists that failure for buckling in the lower flange, in the concrete opening region. The second group comprises the joists in which the failure occurred by the diagonal buckling. Finally, the third one discusses the results regarding the deflections.

\subsection{Failure due to buckling of the lower flange}

The maximum bending moment and internal forces in the truss are shown in Figure 11.

Where $\boldsymbol{h}$ is the height of the truss; $\boldsymbol{R}_{c}$ is the compression force resulting in the lower flange; and $\boldsymbol{R}_{t}$ is the tension force resulting in the upper flange.

The value of $\boldsymbol{R}_{c}$ is determined by Equation 5 .

$\boldsymbol{R}_{c}=\frac{\boldsymbol{M}_{\max }}{\boldsymbol{h}}$

As the lower flange is composed by 2 steel bars, the resulting compression force acting in one of the bars $\left(\boldsymbol{F}_{c}\right)$ in given by Equation 6 . $\boldsymbol{F}_{c}=\frac{\boldsymbol{R}_{c}}{2}$
The Euler critical buckling load $\left(\boldsymbol{P}_{c r}\right)$ for compressed elements is determined by Equation 7 .

$\boldsymbol{P}_{c r}=\frac{\pi^{2} \cdot E_{s} \cdot I_{\emptyset, \text { inf }}}{l_{e, \text { theoretical }}^{2}}$

where is the elasticity modulus of the steel truss taken as 21000 $\mathrm{kN} / \mathrm{cm}^{2} ; \quad l_{\text {e,theoretical }}$ is the theoretical effective length of the bar; and $\vee \boldsymbol{I}_{\phi, \text { inf }}$ is the gross moment of inertia of the lower flange (Equation 8).

$I_{\phi, i n f}=\frac{\pi \cdot \phi_{i n f}^{4}}{64}$

where $\phi_{i n f}$ is the diameter of one lower flange steel bar.

The monolithism provided by the welding in the truss nodes and the fixity of the bars in the concrete base shall interfere in the compressed elements effective buckling length. The lower flanges have theoretical effective lengths equal to 20,30 and $40 \mathrm{~cm}-$ which refer to the concrete opening widths. If equal to $\boldsymbol{P}_{c r}$, it is possible to calculate the real effective length $\left(\boldsymbol{l}_{e, \text { real }}\right)$ of the truss element (Equation 9).

$l_{e, \text { real }}=\sqrt{\frac{\pi^{2} \cdot E_{s} \cdot I_{\phi, i n f}}{F_{c}}}$

The results of $\boldsymbol{l}_{\boldsymbol{e} \text {,real }}$ for the lattice joists that failure for lower flange buckling are summarized in Table 3, where 'Avrg' is the abbreviation for Average.

The ratio between the real effective length and the theoretical effective length is smaller than 1 . It indicates that there is some stiffening in the lower truss bars possibly due to two reasons. One reason is related to the truss nodes, regarding the fact that an electro welded truss doesn't have fully pinned nodes, as it is considered in the classical mechanics. Another reason is related to the fixity of the lower bars to the concrete base of the joist. The lattice trusses
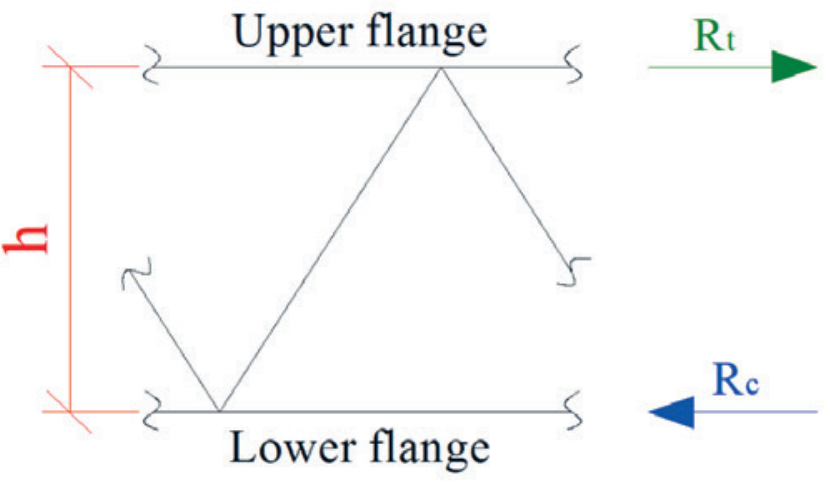

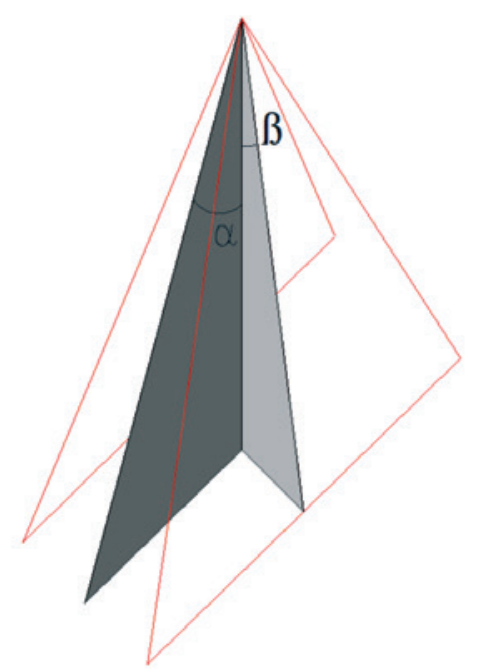

\section{Figure 11}

Resulting internal forces and bending moment in the truss

Source: Authors 
with a height of 25 and $30 \mathrm{~cm}$ did not achieve lower flange failure, when the concrete opening was only of $20 \mathrm{~cm}$. For these cases, the failure occurs in the diagonals.

\subsection{Failure due to diagonal bars buckling}

The maximum shear force in a lattice joist introduces compression stresses in its diagonals. The compression force $(\boldsymbol{Q})$ in a truss diagonal is given by Equation 10

$Q=\frac{V_{\max }}{4 \cdot \cos \alpha \cdot \sin \beta}$ where $\alpha$ and $\beta$ are the truss angles, respectively defined by Equation 11 and 13:

$$
\begin{aligned}
& \alpha=\operatorname{arctg}\left(\frac{10}{h}\right) \\
& \beta=\operatorname{arctg}\left(\frac{z}{2 . h}\right)
\end{aligned}
$$

where $\boldsymbol{h}$ is the height of the truss in centimeters; $\boldsymbol{z}$ in the spacing between the two bars of the lower flanges, in centimeters, and is always the value of $9 \mathrm{~cm}$ for all the tested lattice joists.

When the compression force $\boldsymbol{Q}$ is equal to the Euler critical

Table 3

\begin{tabular}{|c|c|c|c|c|}
\hline Model & $\begin{array}{l}I_{\text {erreal }} \\
(\mathrm{cm})\end{array}$ & $\begin{array}{l}I_{\text {e,theoret }} \\
(\mathrm{cm})\end{array}$ & $\left.\right|_{e, \text { theal }}$ & Avrg \\
\hline VT 06201 & 6.88 & 20 & 0.34 & \multirow{3}{*}{0.35} \\
\hline VT 06202 & 7.19 & 20 & 0.36 & \\
\hline VT 06203 & 7.12 & 20 & 0.36 & \\
\hline VT 06301 & 7.65 & 30 & 0.25 & \multirow{3}{*}{0.26} \\
\hline VT 06302 & 7.72 & 30 & 0.26 & \\
\hline VT 06303 & 7.81 & 30 & 0.26 & \\
\hline VT 06401 & 8.04 & 40 & 0.2 & \multirow{3}{*}{0.21} \\
\hline VT 06402 & 7.83 & 40 & 0.2 & \\
\hline VT 06403 & 8.82 & 40 & 0.22 & \\
\hline VT 08201 & 7.74 & 20 & 0.39 & \multirow{3}{*}{0.38} \\
\hline VT 08202 & 7.70 & 20 & 0.39 & \\
\hline VT 08203 & 7.24 & 20 & 0.36 & \\
\hline VT 08301 & 8.65 & 30 & 0.29 & \multirow{3}{*}{0.29} \\
\hline VT 08302 & 8.58 & 30 & 0.29 & \\
\hline VT 08303 & 8.78 & 30 & 0.29 & \\
\hline VT 08401 & 8.91 & 40 & 0.22 & \multirow{3}{*}{0.23} \\
\hline VT 08402 & 9.62 & 40 & 0.24 & \\
\hline VT 08403 & 9.19 & 40 & 0.23 & \\
\hline VT 10201 & 8.51 & 20 & 0.43 & \multirow{3}{*}{0.42} \\
\hline VT 10202 & 8.14 & 20 & 0.41 & \\
\hline VT 10203 & 8.81 & 20 & 0.44 & \\
\hline VT 10301 & 9.70 & 30 & 0.32 & \multirow{3}{*}{0.32} \\
\hline VT 10302 & \multicolumn{3}{|c|}{ Discarded } & \\
\hline VT 10303 & 9.56 & 30 & 0.32 & \\
\hline VT 10401 & 10.38 & 40 & 0.26 & \multirow{3}{*}{0.25} \\
\hline VT 10402 & 9.68 & 40 & 0.24 & \\
\hline VT 10403 & 10.27 & 40 & 0.26 & \\
\hline VT 12201 & 8.38 & 20 & 0.42 & \multirow{3}{*}{0.43} \\
\hline VT 12202 & 8.64 & 20 & 0.43 & \\
\hline VT 12203 & 9.04 & 20 & 0.45 & \\
\hline VT 12301 & 10.71 & 30 & 0.36 & \multirow{3}{*}{0.34} \\
\hline VT 12302 & 10.18 & 30 & 0.34 & \\
\hline VT 12303 & 9.65 & 30 & 0.32 & \\
\hline VT 12401 & 10.49 & 40 & 0.26 & \multirow{3}{*}{0.28} \\
\hline VT 12402 & 11.61 & 40 & 0.29 & \\
\hline VT 12403 & 11.60 & 40 & 0.29 & \\
\hline
\end{tabular}

Values of $\mathrm{I}_{\text {ereal }}$ for lattice joists with lower flange buckling failure

\begin{tabular}{|c|c|c|c|c|}
\hline Model & $\begin{array}{l}I_{\text {e,real }} \\
(\mathrm{cm})\end{array}$ & $\begin{array}{l}\mathrm{I}_{\text {e.theoret }} \\
(\mathrm{cm})\end{array}$ & $\begin{array}{c}I_{e, \text { real }} \\
\Gamma_{e, \text { theoret }}\end{array}$ & Avrg \\
\hline VT 16201 & 10.22 & 20 & 0.51 & \\
\hline VT 16202 & 10.94 & 20 & 0.55 & 0.53 \\
\hline VT 16203 & 10.51 & 20 & 0.53 & \\
\hline VT 16301 & 13.03 & 30 & 0.43 & \\
\hline VT 16302 & 13.77 & 30 & 0.46 & 0.44 \\
\hline VT 16303 & 13.17 & 30 & 0.44 & \\
\hline VT 16401 & 14.70 & 40 & 0.37 & \\
\hline VT 16402 & 14.59 & 40 & 0.36 & 0.36 \\
\hline VT 16403 & 14.32 & 40 & 0.36 & \\
\hline VT 20201 & 12.71 & 20 & 0.64 & \\
\hline VT 20202 & 13.24 & 20 & 0.66 & 0.63 \\
\hline VT 20203 & 12.04 & 20 & 0.60 & \\
\hline VT 20301 & 13.67 & 30 & 0.46 & \\
\hline VT 20302 & 12.86 & 30 & 0.43 & 0.45 \\
\hline VT 20303 & 13.78 & 30 & 0.46 & \\
\hline VT 20401 & 15.25 & 40 & 0.38 & \\
\hline VT 20402 & 16.11 & 40 & 0.40 & 0.40 \\
\hline VT 20403 & 16.77 & 40 & 0.42 & \\
\hline VT 25201 & \multirow{3}{*}{\multicolumn{4}{|c|}{ Not applicable }} \\
\hline VT 25202 & & & & \\
\hline VT 25203 & & & & \\
\hline VT 25301 & 15.01 & 30 & 0.50 & \multirow{3}{*}{0.53} \\
\hline VT 25302 & 17.39 & 30 & 0.58 & \\
\hline VT 25303 & 15.23 & 30 & 0.51 & \\
\hline VT 25401 & 17.97 & 40 & 0.45 & \multirow{3}{*}{0.45} \\
\hline VT 25402 & 18.13 & 40 & 0.45 & \\
\hline VT 25403 & 17.81 & 40 & 0.45 & \\
\hline VT 30201 & \multirow{3}{*}{\multicolumn{4}{|c|}{ Not applicable }} \\
\hline VT 30202 & & & & \\
\hline VT 30203 & & & & \\
\hline VT 30301 & 16.79 & 30 & 0.56 & \multirow{3}{*}{0.56} \\
\hline VT 30302 & 16.74 & 30 & 0.56 & \\
\hline VT 30303 & 16.78 & 30 & 0.56 & \\
\hline VT 30401 & 19.47 & 40 & 0.49 & \multirow{3}{*}{0.49} \\
\hline VT 30402 & 19.59 & 40 & 0.49 & \\
\hline VT 30403 & 19.14 & 40 & 0.48 & \\
\hline
\end{tabular}




\section{Table 4}

Values of $\mathrm{I}_{\text {ereal }}$ for the lattice joists which presented a failure mode due to buckling of the diagonal bars

\begin{tabular}{|c|c|c|c|c|}
\hline Model & $\begin{array}{l}\text { Ie,real,d } \\
(\mathrm{cm})\end{array}$ & $\begin{array}{l}\mathrm{I}_{\text {e.theoret, d }} \\
(\mathrm{Cm})\end{array}$ & $\mathrm{I}_{\mathrm{e}, \text { theoret,d }}^{\mathrm{I}_{\mathrm{e}} \text {,eal, }}$ & Avrg \\
\hline VT 25201 & \multicolumn{3}{|c|}{ Discarded } & \multirow{3}{*}{0.40} \\
\hline VT 25202 & 10.99 & 27.30 & 0.40 & \\
\hline VT 25203 & 10.78 & 27.30 & 0.39 & \\
\hline VT 25301 & 11.02 & 27.30 & 0.40 & \multirow{3}{*}{0.43} \\
\hline VT 25302 & 12.77 & 27.30 & 0.47 & \\
\hline VT 25303 & 11.18 & 27.30 & 0.41 & \\
\hline VT 25401 & 12.81 & 27.30 & 0.47 & \multirow{3}{*}{0.47} \\
\hline VT 25402 & 12.92 & 27.30 & 0.47 & \\
\hline VT 25403 & 12.69 & 27.30 & 0.46 & \\
\hline
\end{tabular}

\begin{tabular}{|c|c|c|c|c|}
\hline Model & $\begin{array}{l}I_{\text {e,real, }} \\
(\mathrm{cm})\end{array}$ & $\begin{array}{l}\text { Ie.theoret,d } \\
(\mathrm{cm})\end{array}$ & $I_{\text {e,theoret,d }}^{I_{e, \text { eal }}}$ & Avrg \\
\hline VT 30201 & 10.67 & 31.94 & 0.33 & \multirow{3}{*}{0.33} \\
\hline VT 30202 & 10.40 & 31.94 & 0.33 & \\
\hline VT 30203 & 10.82 & 31.94 & 0.34 & \\
\hline VT 30301 & 10.41 & 31.94 & 0.33 & \multirow{3}{*}{0.33} \\
\hline VT 30302 & 10.38 & 31.94 & 0.33 & \\
\hline VT 30303 & 10.41 & 31.94 & 0.32 & \\
\hline VT 30401 & 11.71 & 31.94 & 0.37 & \multirow{3}{*}{0.37} \\
\hline VT 30402 & 11.78 & 31.94 & 0.37 & \\
\hline VT 30403 & 11.52 & 31.94 & 0.36 & \\
\hline
\end{tabular}

buckling load $\boldsymbol{P}_{c r}$ (Equation 7), it is possible to obtain the real effective buckling length of the truss girder diagonals $\left(\boldsymbol{l}_{\boldsymbol{e}, \text { real }, \boldsymbol{d}}\right)$, given b Equation 13.

$l_{e, \text { real }, d}=\sqrt{\frac{\pi^{2} \cdot E_{s} \cdot I_{\phi, d i g}}{Q}}$

where $\boldsymbol{I}_{\phi, d i g}$ is the moment of inertia of a diagonal bar (Equation 14).

$I_{\phi, d i g}=\frac{\pi \cdot \phi_{d i g}^{4}}{64}$

where $\phi_{\text {dig }}$ is the diameter of the diagonal steel bar.

The diagonal theoretical effective buckling length $\left(\boldsymbol{l}_{\boldsymbol{e}, \text { theoretical }, \boldsymbol{d}}\right)$ is determined by Equation 15, in centimeters.

$l_{\text {e,theoretical, }}=\sqrt{\left(\frac{z}{2}\right)^{2}+h^{2}+100}$

From Equations 13 and 15 it is possible to calculate the ratio

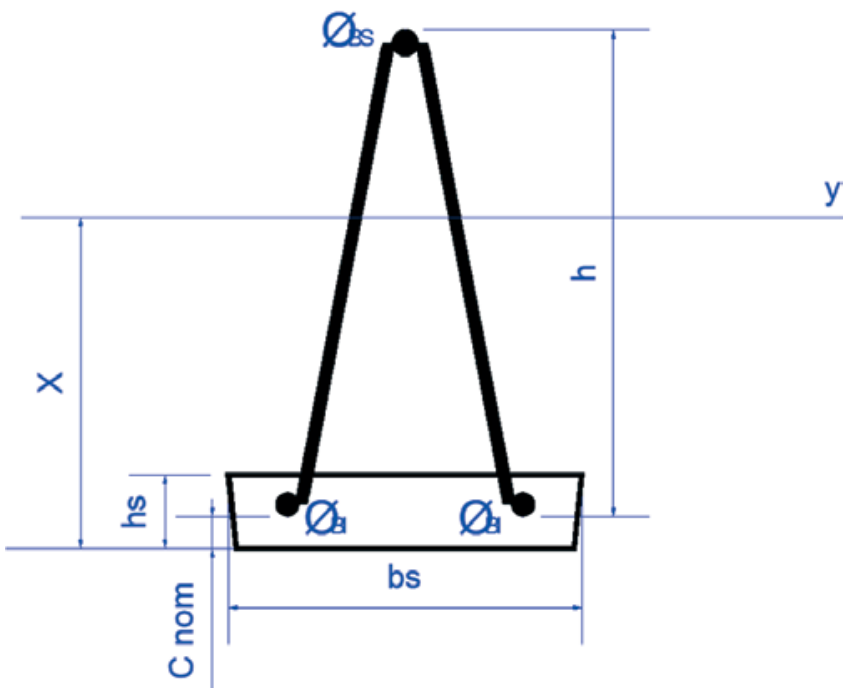

Figure 12

Joist cross section

Source: Authors

between real and theoretical effective length. Results for the samples that failure of the lattice joist was due to buckling of the diagonals are presented in Table 4 . The results are regarding to trusses with heights of 25 and $30 \mathrm{~cm}$, as far as the failure mode described in this item only occurred for these geometry. For other values of height, the buckling of diagonal bars is not the predominant failure mode for the proposed test set-up.

The fixity of the welded nodes and the embedment of the diagonal bars in the joist concrete strongly reduce the effective buckling length of the diagonal bars.

\subsection{Deflection analysis}

The deflection calculation is particularly complex in the step of analysis of results due to the composite cross section of the lattice joist - one of the section regions is composed by concrete and steel, while the other one is only composed by the steel truss bars. The moments of inertia are calculated separately for each region of the cross section mentioned above (Equations 16 to 22).

Properties of the transformed section

$\alpha_{e}=\frac{E_{s}}{E_{c s}}$

$x=\frac{\left[\frac{\phi_{B S}^{2}}{4} \cdot\left(h-\frac{\phi_{B S}}{2}+c_{n o m}\right)+\frac{\phi_{B I}^{2}}{2} \cdot\left(\frac{\phi_{B I}}{2}+c_{n o m}\right)\right] \cdot \pi \cdot \alpha_{e}+\frac{h_{s}^{2} \cdot b_{s}}{2}}{\left(\frac{\phi_{B S}^{2}}{4}+\frac{\phi_{B I}^{2}}{2}\right) \cdot \pi \cdot \alpha_{e}+h_{s} \cdot b_{s}}$

$I_{H}=\frac{\pi \cdot \phi_{B S}^{4}}{64}+\frac{\pi \cdot \phi_{B I}^{4}}{32}+$

$\left[\frac{\phi_{B S}^{2}}{4} \cdot\left(h+c_{n o m}-x-\frac{\phi_{B S}}{2}\right)^{2}+\frac{\phi_{B I}^{2}}{2} \cdot\left(x-\frac{\phi_{B I}}{2}-c_{n o m}\right)^{2}\right]$.

$\pi . \alpha_{e}++\frac{h_{s}^{3} \cdot b_{s}}{12}+h_{s} \cdot b_{s} \cdot\left(x-\frac{h_{s}}{2}\right)^{2}$

The parameters indicated in Equations 16 and 18 are shown in Figure 12: $x$ is the distance from the center of gravity position (of the transformed cross section) to the bottom face of the section; 
$I_{H}$ is moment of inertia of the transformed cross section; $\phi_{B S}$ is the diameter of the upper flange bar;

$\phi_{B I}$ is the diameter of the lower flange bars; $h$ is the height of the lattice truss; $c_{n \text { nom }}$ is the concrete cover for the lower flange bars, always equal to $1.5 \mathrm{~cm}$ along this research; $b_{s}$ is the width of the concrete joist base, always equal to $12.0 \mathrm{~cm}$ for the present tests; $h_{s}$ is the height of the concrete, taken as $2.5 \mathrm{~cm}$ in this research; $\alpha_{e}$ is the ratio between the steel modulus of elasticity $\left(E_{s}\right)$ taken as $21000 \mathrm{kN} / \mathrm{cm}^{2}$, and the concrete secant modulus of elasticity $\left(E_{c s}\right)$ given by Equation 19.

$E_{c s}=\alpha_{i} \cdot E_{c i}$

where $E_{c i}$ is the tangent modulus of elasticity of the concrete; $\alpha_{i}$ is a parameter defined by Equation 20, which depends on the characteristic compressive concrete strength $f_{c k}(\mathrm{MPa})$. As mentioned before, the $E_{c i}$ value is approximately $20 \%$ to $40 \%$ smaller than the dynamic elasticity modulus. In this article, the elasticity modulus values presented in Table 1 were reduced in $30 \%$ in order to correlate the dynamic and static modulus of elasticity.

$\alpha_{i}=0,8+0,2 \cdot \frac{f_{c k}}{80} \leq 1,0$

Properties of the section composed only for the steel truss bars

$x_{1}=\frac{\frac{\pi \cdot \phi_{B I}^{3}}{4}+\frac{\pi \cdot \phi_{B S}^{2}}{4} \cdot\left(h-\frac{\phi_{B S}}{2}\right)}{\frac{\pi \cdot \phi_{B I}^{2}}{2}+\frac{\pi \cdot \phi_{B S}^{2}}{4}}$

$I_{S}=\left[\frac{\pi \cdot \phi_{B S}^{4}}{64}+\frac{\pi \cdot \phi_{B S}^{2}}{4} \cdot\left(h-x_{1}-\frac{\phi_{B S}}{2}\right)^{2}\right]+$

(22)

$2 \cdot\left[\frac{\pi \cdot \phi_{B I}^{4}}{64}+\frac{\pi \cdot \phi_{B I}^{2}}{4} \cdot\left(x_{1}-\frac{\phi_{B I}}{2}\right)^{2}\right]$

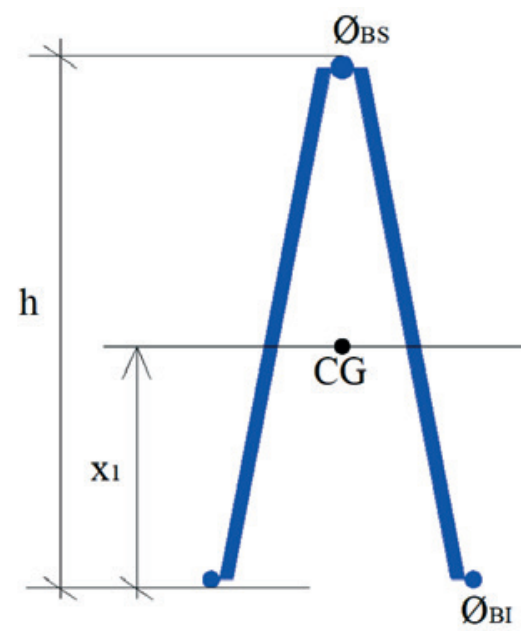

Figure 13

Center of gravity position for the lattice truss steel elements

Source: Authors
According to the Figure 13, the parameters used in Equations 21 and 22 are: $x_{1}$ is the distance between the center of gravity of the section and its bottom base; $I_{S}$ is the moment of inertia of the steel section; $\phi_{B S}$ is the diameter of the upper flange bar; $\phi_{B I}$ is the diameter of the lower flange bars; $h$ is the height of the lattice truss. Considering Figure 10, it is observed that for $a$ e $b$ segments the moment of inertia is equal to $\boldsymbol{I}_{\boldsymbol{H}}$, whereas the moment of inertia is equal to $\boldsymbol{I}_{\boldsymbol{s}}$ for segment $c$. The values for the experimental deflection are taken in the application load points $(P)$. Therefore, the theoretical deflection value, analyzing the same point, is given by Equation 23.

$a_{P}=-\frac{1}{\left(E_{c S} \cdot I_{H}\right) \text { theoretical }}$.

$\left.\left\{\begin{array}{c}-\frac{p p \cdot a^{2} \cdot b^{2}}{4}-\frac{p p \cdot a \cdot b^{3}}{6}-\frac{p p \cdot b^{4}}{24}+\frac{R \cdot b^{3}}{6}+ \\ \frac{p p \cdot a^{2} \cdot b}{2}+\frac{p p \cdot a \cdot b^{2}}{2}+\frac{p p \cdot b^{3}}{6}-\frac{R \cdot b^{2}}{2}+ \\ +\frac{\left(E_{\text {cs. }} I_{H}\right)_{\text {theoretical }}}{\left(E_{S} \cdot I_{S}\right)_{\text {theoretical }}} \cdot\left(\begin{array}{c}-\frac{p p \cdot c \cdot\left(a^{2}+b^{2}\right)}{4}-\frac{p p \cdot a \cdot b \cdot c}{2}+ \\ -\frac{p p \cdot c^{2} \cdot(a+b)}{8}-\frac{p p \cdot c^{3}}{48}+ \\ -\frac{F_{\text {lim }} \cdot c^{2}}{16}+\frac{R \cdot b \cdot c}{2}++\frac{R \cdot c^{2}}{8}\end{array}\right)\end{array}\right]\right\}$

Rewriting the expression, Equation 24 is obtained.

$a_{P}=-\frac{1}{\left(E_{c s} \cdot I_{H}\right) \text { theoretical }} \cdot\left[\frac{p p \cdot a^{2} \cdot b^{2}}{4}+\frac{p p \cdot a \cdot b^{3}}{3}+\frac{p p \cdot b^{4}}{8}-\frac{R \cdot b^{3}}{3}\right]+$

$-\frac{1}{\left(E_{c s} \cdot I_{H}\right) \text { theoretical }} \cdot\left(\begin{array}{c}-\frac{p p \cdot b \cdot c \cdot\left(a^{2}+b^{2}\right)}{4}-\frac{p p \cdot a \cdot b^{2} \cdot c}{2}-\frac{p p \cdot b \cdot c \cdot(a+b)}{8}+ \\ -\frac{p p \cdot b \cdot c^{3}}{48}-\frac{F_{l i m \cdot b \cdot c^{2}}}{16}+\frac{R \cdot b^{2} \cdot c}{2}+\frac{R \cdot b \cdot c^{2}}{8}\end{array}\right)$

$R=\frac{F_{l i m}}{2}+p p \cdot\left(a+b+\frac{c}{2}\right)$

where $\left(E_{c s} \cdot I_{H}\right)_{\text {theoretical }}$ is the theoretical stiffness of the transformed joist and $\left(E_{s} . I_{s}\right)_{\text {theoretical }}$ is the theoretical stiffness of the lattice truss steel section. If $a_{P}$ is equal to the limit deflection $a_{\text {lim }}$, Equation 26 is obtained.

$$
\left(E_{c s} \cdot I_{H}\right)_{\text {real }}=\frac{\left[-\frac{p p \cdot a^{2} \cdot b^{2}}{4}-\frac{p p \cdot a \cdot b^{3}}{3}-\frac{p p \cdot b^{4}}{8}+\frac{R \cdot b^{3}}{3}\right]}{0,40+\frac{1}{\left(E_{s} \cdot I_{s}\right)_{\text {theoretical }}} \cdot\left(\begin{array}{c}
-\frac{p p \cdot b \cdot c\left(a^{2}+b^{2}\right)}{4}-\frac{p p \cdot a \cdot b^{2} \cdot c}{2} \\
-\frac{p p \cdot b \cdot c^{2} \cdot(a+b)}{8}+ \\
-\frac{p p \cdot b \cdot c^{3}}{48}-\frac{F_{l i m} \cdot b \cdot c^{2}}{16}+ \\
\frac{R \cdot b^{2} \cdot c}{2}+\frac{R \cdot b \cdot c^{2}}{8}
\end{array}\right)}
$$

$\left(E_{c s} \cdot I_{H}\right)_{\text {real }}$ is the mean stiffness of the testes joist that will be used for the deflection calculation. This stiffness is different from the theoretical stiffness due to the concrete cracking. Table 5 presents the results of the deflection values. It can be seen that the real 
stiffness $\left(E_{c s} \cdot I_{H}\right)_{\text {real }}$ is much smaller than the theoretical one. The discontinuity occasioned by the concrete opening and the concrete cracking explain this reduction. In the theoretical calculation, the value for the neutral axis position results in some point close to the concrete footing, indicating that concrete cracking is occurring.

\section{Results applicability}

As mentioned in item 1, during the assembly of a cantilever slab with concrete opening in the region right over the supports, there is a need of knowing the lattice joist strength during the construction phase. In this phase, the lattice joist will support itself the weight of the fresh concrete, of the workers and of the concreting equipment. The failure modes visually observed in the tests were: lower flange buckling due to hogging moments and diagonal bars buckling due to shear forces. Besides this modes of failure, it can still occur the failure of the welded node due to shear forces.

When a joist, mini panel or panel is loaded and positioned over the supports, bending moments and shear loads will develop. For cases of sagging moments acting on the structure, the adequate equation can be found in Sartorti et al [3]. For cases of hogging moments acting on the structure in regions where a concrete opening exists, the present article defines equations for calculating the resisting hogging moment and shear forces.

\section{Table 5}

Results of deflection values

\begin{tabular}{|c|c|c|c|c|}
\hline Model & $\begin{array}{c}\text { Concrete } \\
\text { mixture }\end{array}$ & $\left(E_{c s} \cdot I_{H}\right)_{\text {real }}$ & $\begin{array}{l}\left(E_{c s} \cdot I_{H}\right)_{\text {real }} \\
\left(E_{c s} \cdot I_{H}\right)_{\text {theoret }}\end{array}$ & Avrg \\
\hline VT 06201 & 14 & 155321.61 & 0.68 & \multirow{3}{*}{0.67} \\
\hline VT 06202 & 15 & 153670.84 & 0.67 & \\
\hline VT 06203 & 15 & 153898.86 & 0.67 & \\
\hline VT 06301 & 14 e 15 & 109085.05 & 0.48 & \multirow{3}{*}{0.47} \\
\hline VT 06302 & 14 & 106071.52 & 0.46 & \\
\hline VT 06303 & 14 & 106001.81 & 0.46 & \\
\hline VT 06401 & 14 & 81921.97 & 0.36 & \multirow{3}{*}{0.35} \\
\hline VT 06402 & 15 & 81117.07 & 0.36 & \\
\hline VT 06403 & 13 e 14 & 76077.79 & 0.33 & \\
\hline VT 08201 & 13 & 244466.56 & 0.64 & \multirow{3}{*}{0.63} \\
\hline VT 08202 & 13 & 225608.62 & 0.59 & \\
\hline VT 08203 & 13 & 246429.20 & 0.65 & \\
\hline VT 08301 & 13 & 163054.65 & 0.43 & \multirow{3}{*}{0.42} \\
\hline VT 08302 & 13 & 164707.40 & 0.43 & \\
\hline VT 08303 & 13 & 156758.64 & 0.41 & \\
\hline VT 08401 & 12 & 125388.10 & 0.33 & \multirow{3}{*}{0.32} \\
\hline VT 08402 & 12 & 118529.19 & 0.31 & \\
\hline VT 08403 & 12 & 118798.22 & 0.31 & \\
\hline VT 10201 & 8 & 292534.04 & 0.51 & \multirow{3}{*}{0.51} \\
\hline VT 10202 & 8 & 288632.99 & 0.50 & \\
\hline VT 10203 & 8 & 302612.31 & 0.53 & \\
\hline VT 10301 & 9 & 212033.91 & 0.37 & \multirow{3}{*}{0.36} \\
\hline VT 10302 & 9 & \multicolumn{2}{|c|}{ Discarded } & \\
\hline VT 10303 & 9 & 211147.67 & 0.36 & \\
\hline VT 10401 & 10 & 159338.07 & 0.27 & \multirow{3}{*}{0.28} \\
\hline VT 10402 & 10 & 171124.24 & 0.29 & \\
\hline VT 10403 & 10 & 161330.79 & 0.28 & \\
\hline VT 12201 & 11 & 364945.36 & 0.44 & \multirow{3}{*}{0.45} \\
\hline VT 12202 & 11 e 12 & 369795.56 & 0.45 & \\
\hline VT 12203 & 12 & 364380.21 & 0.44 & \\
\hline VT 12301 & 11 & 252972.47 & 0.31 & \multirow{3}{*}{0.33} \\
\hline VT 12302 & 11 & 267979.65 & 0.33 & \\
\hline VT 12303 & 11 & 280947.89 & 0.34 & \\
\hline VT 12401 & 10 & 195258.00 & 0.24 & \multirow{3}{*}{0.23} \\
\hline VT 12402 & 10 e 11 & 180423.56 & 0.22 & \\
\hline VT 12403 & 10 & 180503.02 & 0.22 & \\
\hline
\end{tabular}

\begin{tabular}{|c|c|c|c|c|}
\hline Model & $\begin{array}{c}\text { Concrete } \\
\text { mixture }\end{array}$ & $\left(\mathrm{E}_{\mathrm{cs}} \cdot \mathrm{I}_{\mathrm{H}}\right)_{\text {real }}$ & \begin{tabular}{|l|}
$\left(\mathrm{E}_{\mathrm{cs}} \mathrm{I}_{\mathrm{H}}\right)_{\text {real }}$ \\
$\left(\mathrm{E}_{\mathrm{cs}} \mathrm{I}_{\mathrm{H}}\right)_{\text {theoret }}$
\end{tabular} & Avrg \\
\hline VT 16201 & 6 & 655614.76 & 0.35 & \multirow{3}{*}{0.34} \\
\hline VT 16202 & 6 & 580841.79 & 0.31 & \\
\hline VT 16203 & 6 & 50375.24 & 0.35 & \\
\hline VT 16301 & 7 & 50662.25 & 0.24 & \multirow{3}{*}{0.25} \\
\hline VT 16302 & 7 & 60356.94 & 0.25 & \\
\hline VT 16303 & 7 & 472568.42 & 0.25 & \\
\hline VT 16401 & 8 & 355565.70 & 0.19 & \multirow{3}{*}{0.19} \\
\hline VT 16402 & 8 & 359303.44 & 0.19 & \\
\hline VT 16403 & 7 & 369402.60 & 0.20 & \\
\hline VT 20201 & 5 & 622823.28 & 0.21 & \multirow{3}{*}{0.21} \\
\hline VT 20202 & 4 & 595495.63 & 0.20 & \\
\hline VT 20203 & 5 & 616838.05 & 0.21 & \\
\hline VT 20301 & 5 & 717295.38 & 0.24 & \multirow{3}{*}{0.21} \\
\hline VT 20302 & 5 & 580981.72 & 0.20 & \\
\hline VT 20303 & 5 & 577835.01 & 0.20 & \\
\hline VT 20401 & 6 & 419473.45 & 0.14 & \multirow{3}{*}{0.13} \\
\hline VT 20402 & 6 & 392026.70 & 0.13 & \\
\hline VT 20403 & 6 & 352356.85 & 0.12 & \\
\hline VT 25201 & 1 & \multicolumn{2}{|c|}{ Discarded } & \multirow{3}{*}{0.18} \\
\hline VT 25202 & 1 & 757046.84 & 0.16 & \\
\hline VT 25203 & 1 & 885769.99 & 0.19 & \\
\hline VT 25301 & 1 & 702880.20 & 0.15 & \multirow{3}{*}{0.16} \\
\hline VT 25302 & 2 & 822666.67 & 0.18 & \\
\hline VT 25303 & 1 and 2 & 657050.13 & 0.14 & \\
\hline VT 25401 & 2 & 614253.09 & 0.13 & \multirow{3}{*}{0.13} \\
\hline VT 25402 & 2 & 641758.34 & 0.14 & \\
\hline VT 25403 & 2 & 573322.11 & 0.12 & \\
\hline VT 30201 & 3 & 1052186.65 & 0.13 & \multirow{3}{*}{0.12} \\
\hline VT 30202 & 3 & 972026.25 & 0.12 & \\
\hline VT 30203 & 3 & 1036486.34 & 0.12 & \\
\hline VT 30301 & 3 & 809006.88 & 0.10 & \multirow{3}{*}{0.10} \\
\hline VT 30302 & 3 & 876744.26 & 0.10 & \\
\hline VT 30303 & 4 & 932740.84 & 0.11 & \\
\hline VT 30401 & 4 & 857489.47 & 0.10 & \multirow{3}{*}{0.10} \\
\hline VT 30402 & 4 & 768769.84 & 0.09 & \\
\hline VT 30403 & 4 & 778578.07 & 0.09 & \\
\hline
\end{tabular}




\subsection{Lower flange buckling due to hogging moments}

The Equations 27 to 30 are deduced and based on the prior equations presented in this paper. The resisting bending moment (negative bending moment) is defined by Equation 29.

$M_{d, r e s}=P_{C R} \cdot h$

$P_{C R}=\frac{2 \cdot \pi^{2} \cdot E_{s} \cdot I_{\phi, i n f}}{l_{e, \text { real }}^{2}}$

$M_{d, \text { res }}=\frac{2 \cdot \pi^{2} \cdot E_{s} \cdot I_{\phi, i n f}}{l_{e, \text { real }}^{2}} \cdot h$

$l_{e, \text { real }}=l_{e, \text { theorical }}$ Avrg

Where $P_{C R}$. is the critical buckling load in the lower flange; $h$ is the height of the truss; $E_{s}$ is the steel modulus of elasticity; $I_{\phi, i n f}$ is the moment of inertia of the lower bars cross section; $l_{e, \text { real }}$ is the real effective buckling length of the lower flange at the concrete opening; $l_{e \text {,theorical }}$ is the theoretical buckling effective length of the lower flange at the concrete opening - which can measure 20, 30 or $40 \mathrm{~cm}$; Avrg is the indicated in the last column of Table 3 .

Structural safety is guaranteed when the following condition is satisfied (Equation 31):

$M_{d, r e s} \geq M_{S d}$

Where $M_{S d}$ is the design bending moment.

\subsection{Diagonal bars buckling due to shear}

The axial force $(Q)$ that compresses a diagonal bar is given by Equation 10. For obtaining Equation 32, the value of $V_{\max }$ was replaced by the design shear force $V_{S d}$, in Equation 10.

$Q=\frac{V_{S d}}{4 \cdot \cos \alpha \cdot \sin \beta}$

The axial critical buckling load $\left(P_{C R, D}\right)$ of a diagonal bar is defined by Equations 33 and 34 .

$P_{C R, D}=\frac{\pi^{2} \cdot E_{s} \cdot I_{\phi, d i g}}{l_{e, r e a l, d}^{2}}$

$l_{e, \text { real }, d}=l_{e, \text { theorical,d }}$. Avrg

where $E_{s}$ is the steel modulus of elasticity; $I_{\phi, d i g}$ is the moment of inertia of the diagonal bar cross section; $v$ is the real effective buckling length of the diagonal bar; $l_{e, t h e o r i c a l, d}$ is the theoretical buckling effective length of the diagonal bar; Avrg is the value indicated in the last column of Table 4.

Structural safety is guaranteed when the following condition is satisfied (Equation 35):

$P_{C R, D} \geq Q$

\subsection{Failure of the welded node}

The upper node shear force resistance $(V)$ shall meet the requirement of Equation 36, adapted from ABNT NBR 14862 [1].

$V=\frac{15 . \pi \cdot \phi_{B S}^{2} \cdot h}{4 . l_{\text {node }}}$

where $\phi_{B S}$ is the diameter of the upper flange bar; $h$ is the height of the truss; $l_{\text {node }}$ is the length between the truss nodes (defined as $20 \mathrm{~cm}$ ); $V_{S d}$ is the design shear force in a transitory phase. Equation 37 shall be satisfied for safety guarantee.

$V_{S d} \leq V$

\subsection{Displacements calculation}

In the transitory phase, it is recommended a limit value for the maximum displacement of the lattice joist, given by the span value divided by 500 ( $l / 500)$. The stiffness values shall be calculated as indicated in Equation 38, using Equations 16 to 22.

$(E I)=(E I)_{\text {theorical }}$ Avrg $=E_{C S} \cdot I_{H} \cdot$ Avrg

where $E_{C S}$ is the secant modulus of elasticity of the concrete; $I_{H}$ is the moment of inertia of the transformed section; Avrg is the value indicated in the last column of Table 5.

\section{Conclusions}

In order to ease the construction of bridge decks, cantilever roofs and eaves, self-supporting lattice joists can be used working as formwork, capable of supporting its own weight, the fresh concrete weight and the weight workers and equipments in the construction phase.

This paper aimed to study the lattice joists behavior under negative bending moments, in cases where there is a concrete opening in the region of joist supports, by carrying out laboratory tests.

For lattice joists with a height of $20 \mathrm{~cm}$ or less, the predominant failure mode was the buckling of the lower flanges of the truss. In the cases of joists 25 or $30 \mathrm{~cm}$ height, with opening of $20 \mathrm{~cm}$ of the concrete, the buckling of diagonal bars governed the failure of the lattice joist. For the same truss height, considering the opening of 30 and $40 \mathrm{~cm}$ of the concrete, the lattice joist failure was governed by the lower flanges buckling.

The two mentioned modes of failure were analyzed separately for the calculation of the real effective buckling length. It was concluded that the diagonal and lower flange bars are stiffened by the electro welded truss nodes and by the fixity of the truss embedded in the concrete joist base. This results in a significant reduction of the effective buckling length. Disposing of the real effective buckling length, it is possible to calculate the maximum bending moments and shear forces resisted by the lattice joist. This values are quite important for the adequate design of the maximum cantilever span with no shuttering, or the maximum span between supports.

For the transition phase calculation, the stiffness value $(E I)$ needs to be calibrated. It was verified that $\left(E_{C S} \cdot I_{H}\right)_{\text {real }}$. is smaller than the theoretical value, due to discontinuity of the concrete in the base of the joist, and concrete cracking. 
The equations for calculating resisting bending moments, shear strength and displacements are indicated in this paper. It is possible to define the maximum cantilever span or the maximum span between supports for a lattice joist with concrete opening, using the mentioned equation.

Studies about mini panels and latticed panels are recommended in order to check possible result variation. The present results show great load carrying capacity of the tested elements. It indicates that lattice joists with concrete opening shall be recommended for situations where monolithism between slabs and joists is desired, and less shuttering is needed, as expected in cases of bridge construction. It is important to emphasize that the present results cannot be extrapolated to models that were not tested, including other lattice joists with different geometry.

\section{References}

[1] ASSOCIAÇÃO BRASILEIRA DE NORMAS TÉCNICAS. NBR 14862. Armaduras treliçadas eletrossoldadas - Requisitos. Rio de Janeiro. 2002.

[2] NBR 14859-1. Laje pré-fabricada - Requisitos Parte 1: Lajes unidirecionais. Rio de Janeiro. 2002.

[3] SARTORTI, A. L.; FONTES, A. C.; PINHEIRO, L. M. Analysis of the assembling phase of lattice slabs. In: Revista IBRACON de Estruturas e Materiais. Volume 6, Number 4 (August 2013) p. 623-660. São Paulo: IBRACON, 2013.

[4] ASSOCIAÇÃO BRASILEIRA DE NORMAS TÉCNICAS. NBR 14859-2. Laje pré-fabricada - Requisitos Parte 2: Lajes bidirecionais. Rio de Janeiro. 2002.

[5] NBR 14860-1. Laje pré-fabricada - Pré-laje - Requisitos Parte 1: Lajes unidirecionais. Rio de Janeiro. 2002.

[6] NBR 14860-2. Laje pré-fabricada - Pré-laje - Requisitos Parte 2: Lajes bidirecionais. Rio de Janeiro. 2002.

[7] NBR 15696. Formas e escoramentos para estruturas de concreto - Projeto, dimensionamento e procedimentos executivos. Rio de Janeiro. 2009

[8] NBR 6118. Projeto de estruturas de concreto - Procedimento. Rio de Janeiro. 2014.

[9] SARTORTI, A. L.; VIZOTTO, I; PINHEIRO, L. M. Utilização de Minipainéis Treliçados para Construção de Tabuleiros de Pontes. Rio de Janeiro: IABSE, 2010.

[10] GASPAR, R. Análise da segurança estrutural das lajes préfabricadas na fase de construção. São Paulo, 1997. 103f. Dissertação (Mestrado em Engenharia de Estruturas)-Escola Politécnica da Universidade de São Paulo.

[11] TERNI, A. W.; MELÃO, A. R.; OLIVEIRA, L. E. A utilização do método dos elementos finitos na análise comportamental da laje treliçada na fase construtiva. Congresso Brasileiro do Concreto, 50. IBRACON. Salvador, 2008.

[12] AMERICAN SOCIETY FOR TESTING AND MATERIALS (ASTM). ASTM E1876-1: Standard test method for dynamic Young's modulus, shear modulus, and Poisson's ratio by impulse excitation of vibration. Philadelphia, 2005.

[13] SARTORTI, A. L. Comportamento dinâmico de lajes maciças de concreto leve com pérolas de EPS. 2015. 215p. Tese (Doutorado) - Departamento de Engenharia de Estruturas da escola de engenharia de São Carlos da Universidade de São Paulo, São Carlos, 2015.

[14] METHA, P. K.; MONTEIRO, P. J. M. Concreto: microestrutura, propriedade e matérias. 2 ed. São Paulo: IBRACON, 2014.

[15] FUSCO, P. B. Tecnologia do concreto estrutural: tópicos aplicados. São Paulo: Pini, 2008. 